\title{
PERUMUSAN STRATEGI BUMDES TARUMAJAYA KAWASAN HULU SUNGAI CITARUM KABUPATEN BANDUNG
}

\author{
Ellen Rusliati \\ ellenrusliati44@gmail.com \\ Mulyaningrum \\ mulyaningrum.unpas@gmail.com
}

Fakultas Ekonomi dan Bisnis Universitas Pasundan

\begin{abstract}
ABSTRAK
Pengabdian ini dimaksudkan agar BUMDES Tarumajaya menjadi outlet bagi produk yang dihasilkan penduduk setempat dan memiliki kinerja yang baik, sehingga dapat berkontribusi pada peningkatan kesejahteraan penduduk. Program normalisasi dan rehabilitasi kawasan hulu sungai Citarum menuntut peran masyarakat agar memberi kontribusi pada normalisasi dan rehabilitasinya. Metode yang dilakukan dengan survey, wawancara, serta pelatihan mengenai manajemen bisnis yaitu memanfaatkan peluang dengan memanfaatkan potensi yang dimiliki. Hasil identifikasi menunjukkan peluang dan kekuatan lebih banyak daripada ancaman dan kelemahannya. Matrik eksternal menunjukkan total skor 2,36 dan matriks internal 2,31. Berdasarkan analisis eksternal internal, menunjukkan BUMDES Tarumajaya berada pada kuadran V, yaitu ditahan dan dijaga, serta strategi yang tepat adalah penetrasi pasar dan pengembangan produk. Program yang dapat dilakukan, antara lain melakukan aktivitas pemasaran dengan memanfaatkan perkembangan teknologi informasi termasuk di dalamnya penelusuran alternatif pengembangan produk baru, sehingga dapat meningkatkan keragaman dan kualitas produk yang dijual serta memahami perkembangan selera konsumen dan pesaing.
\end{abstract}

Kata Kunci: perumusan strategi; matriks eksternal internal; penetrasi pasar; pengembangan produk

\section{PENDAHULUAN}

Situ Cisanti terletak di kawasan Kampung Pejaten, Desa Tarumajaya, Kecamatan Kertasari, Kabupaten Bandung. Lokasinya $60 \mathrm{~km}$ dari kota Bandung. Situ Cisanti merupakan kawasan hulu sungai Citarum. Situ Cisanti dikelilingi oleh beberapa gunung, diantaranya Gunung Malabar, Gunung Rakutak, Gunung Wayang, dan Gunung Bedil. Situ Cisanti adalah danau buatan yang menampung air dari 7 mata air utama Sungai Citarum, yakni mata air Pangsiraman, Cikoleberes, Cikawedukan, Cikahuripan, Cisadane, Cihaniwung, dan Cisanti. Kawasan hulu sungai Citarum merupakan sumber air bagi warga Jawa Barat. Keberadaannya sempat terabaikan, tidak terurus dan dipenuhi oleh eceng gondok. Sampai akhirnya Pangdam III melakukan pembersihan kawasan situ sebagai kawasan terbatas dan senantiasa dijaga oleh TNI AD sampai dengan saat ini (Gambar 1).

Mata pencaharian utama masyarakat desa Tarumajaya adalah di sektor pertanian sebanyak 417 orang, sektor jasa yaitu sebagai buruh tani 4.282 orang, sektor industri sebanyak 431 orang. Permasalahannya adalah masyarakat menanam sayur mayur, seperti kol, bawang daun, kentang, wortel, cabe dan tomat (Kecamatan Kertasari Dalam Angka, 2018) sampai ke lahan kritis dengan kemiringan lebih dari $45^{\circ}$ sehingga rawan longsor. 
Tabel 1 menunjukkan luas dan produksi hasil

\section{Tabel 1}

pertanian desa Tarumaya pada tahun 2017.

Luas dan Produksi Sayuran Desa Tarumajaya tahun 2017

\begin{tabular}{|l|r|r|}
\hline \multicolumn{1}{|c|}{ Produk } & \multicolumn{1}{c|}{ Luas Area (Hektar) } & \multicolumn{1}{c|}{ Produksi (Kwintal) } \\
\hline Cabe & 2,24 & 280 \\
\hline Tomat & 120 & 27.480 \\
\hline Sawi & 120 & 26.400 \\
\hline Bawang Daun & 44,77 & $17.236,45$ \\
\hline Kentang & 220,72 & $43.040,40$ \\
\hline Kubis & 164,77 & $42.016,35$ \\
\hline
\end{tabular}

Sumber: Kecamatan Kertasari dalam Angka, 2018

Adanya intervensi dari TNI AD, baik di

Situ Cisanti dan di lahan kritis sempat mendatangkan penolakan dari penduduk setempat, yang terganggu mata pencahariannya. TNI AD melarang masyarakat melakukan penduduk untuk membuang sampah dan mencari ikan di situ Cisanti juga penanaman sayur mayur di lahan kritis dan menggantinya dengan tanaman keras. Bekerja sama dengan Universitas Pasundan yang konsisten dengan pemeliharaan kawasan hulu sungai Citarum sudah mewajibkan mahasiswa baru untuk membawa biji alpukat sejak 5 tahun lalu untuk ditanam di lahan kritis di sekitar Situ Cisanti (Gambar 2).

Sampai saat ini kawasan Situ Cisanti senantiasa dijaga oleh TNI AD dengan harapan timbulnya kesadaran masyarakat untuk menjaga kelestarian dan kebersihan situ, sebagai sumber air warga Jawa Barat juga penduduk dilarang untuk menanam di lahan kritis. Pengalihan fungsi lahan kritis diperlukan sebagai upaya menjaga lingkungan sebagai serapan air juga mencegah terjadinya musibah longsor.

Alih fungi lahan ini mengakibatkan adanya penduduk yang harus mengganti mata pencahariannya. Upaya yang dilakukan adalah mencoba bedagang di kawasan Situ. Hal ini juga dilarang oleh TNI AD, karena mangganggu keasrian dan keindahan lingkungan. Masyarakat hanya diberikan beberapa lokasi untuk berdagang dan dimanfaatkan oleh BUMDes Tarumajaya.

BUMDes adalah sebuah perusahaan yang dikelola oleh masyarakat desa, yang kepengurusannya terpisah dari pemerintah desa. BUMDes dibentuk untuk menggali potensi wirausaha yang ada di desa dan dikelola oleh warga masyarakat yang mempunyai jiwa wirausaha, diharapkan akan menghasilkan pendapatan asli besar yang diperoleh dari hasil perputaran usaha (Sulaksana dan Nuryanti, 2019). Pengelolaan BUMDes yang dilakukan secara profesional sehingga menghasilkan keuntungan dan dapat menjadi sumber tambahan dalam meningkatkan Pendapatan Asli Desa (Sembiring, 2017). BUMDes merupakan satu alternatif meningkatkan ekonomi di pedesaan (Dewi, 2014; Goma, 2015).

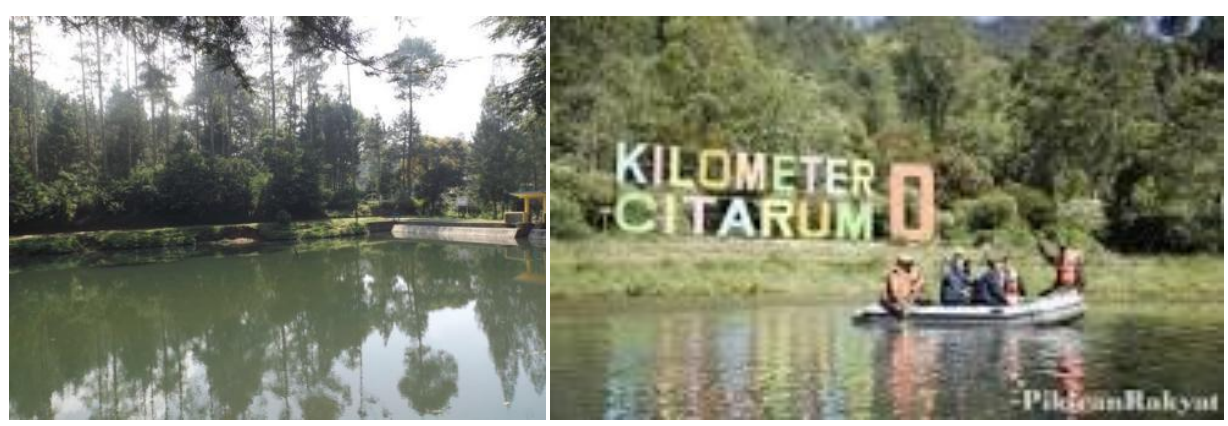

Ekonomi, Sosial, Budaya 


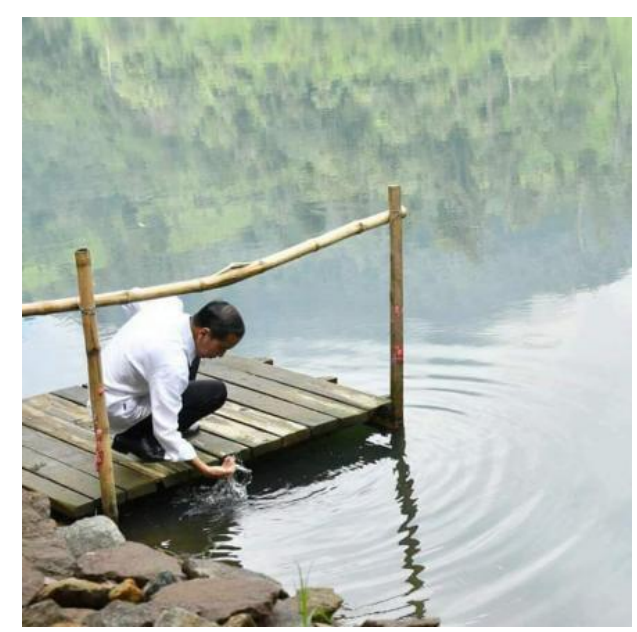

Gambar 1 Situ Cisanti

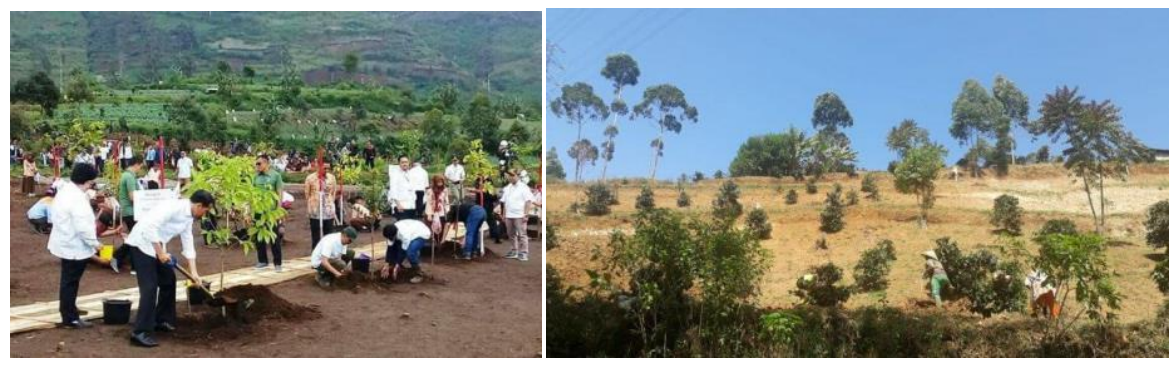

Gambar 2 Kawasan Sekitar Situ Cisanti

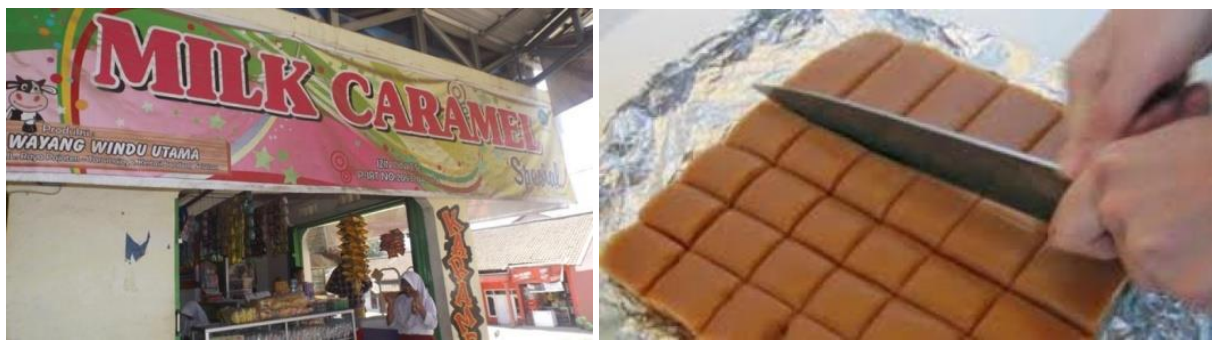

Gambar 3 Produk Olahan Penduduk Sekitar Situ Cisanti

Produk desa Tarumajaya Kecamatan Kertasari antara lain permen susu caramel, wayang golek, kerajinan lukisan, dan iket. Kunjungan wisatawan yang rendah mengakibatkan masyarakat belum mengembangkan produk olahan berbahas dasar lokal, walaupun kemampuan untuk menghasilkan produk seperti keripik kentang, wortel sudah dimiliki, namun hanya dijual berdasarkan pesanan dan untuk keperluan rumah tangga. Belum adanya produk olahan unggulan yang dihasilkan penduduk, menjadilkan BUMDES
Tarumajaya belum dapat beroperasi dan menghasilkan keuntungan sesuai dengan harapan.

\section{METODE}

Metode yang digunakan dalam kegiatan pengabdian masyarakat ini adalah pelatihan, bimbingan teknis, dan pendampingan. Seleksi dilakukan oleh pemerintah desa untuk membatasi peserta yaitu sebanyak 25 orang dengan harapan tujuan pengabdian masyarakat tercapai. Kriteria peserta adalah pengusaha atau calon pengusaha yang beminat untuk mengembangkan usaha atau mewujudkan ide bisnis. Kepala dan sekretaris desa

$$
\text { Ekonomi, Sosial, Budaya }
$$


serta ketua BUMDes Tarumajaya diikutsertakan sebagai pemangku kebijakan dan pengambil keputusan. Kegiatan dilakukan sebanyak 3 kali kunjungan ke lokasi ditambah komunikasi melalui WA Group sebagai sarana komunikasi untuk mengatasi permasalahan.

\section{HASIL DAN PEMBAHASAN}

BUMDes Tarumajaya sudah memiliki bangunan yang layak dengan lokasi di samping kantor pemerintah desa, telah memiliki usaha foto copy dengan jaringan internet yang baik, juga warung makan di lokasi wisata Situ Cisanti. David and David dialih-bahasakan oleh Puspasari dan
Puspitasari (2015) mengemukakan bahwa model strategi meliputi 3 aktivitas, yaitu perumusan, implementasi, dan evaluasi strategi. Perumusan strategi diawali dengan penyusunan matriks faktor ekstrnal dan internal untuk mengetahui peluang dan ancaman serta kekuatan dan kelemahan suatu bisnis, selanjutnya dibuatkan matrik internal eksternal untuk menentukan strategi yang tepat untuk bisnis dimaksud berdasarkan total faktor internal dan eksternal yang diperoleh. Tabel 2 adalah matriks faktor ekstrnal dan internal yang disusun berdasarkan analisis penulis berdasarkan hasil observasi dan wawancara kemudian dikonfirmasikan ke pengurus BUMDes.

Tabel 2

Matriks Faktor Ekstrnal BUMDES Tarumajaya

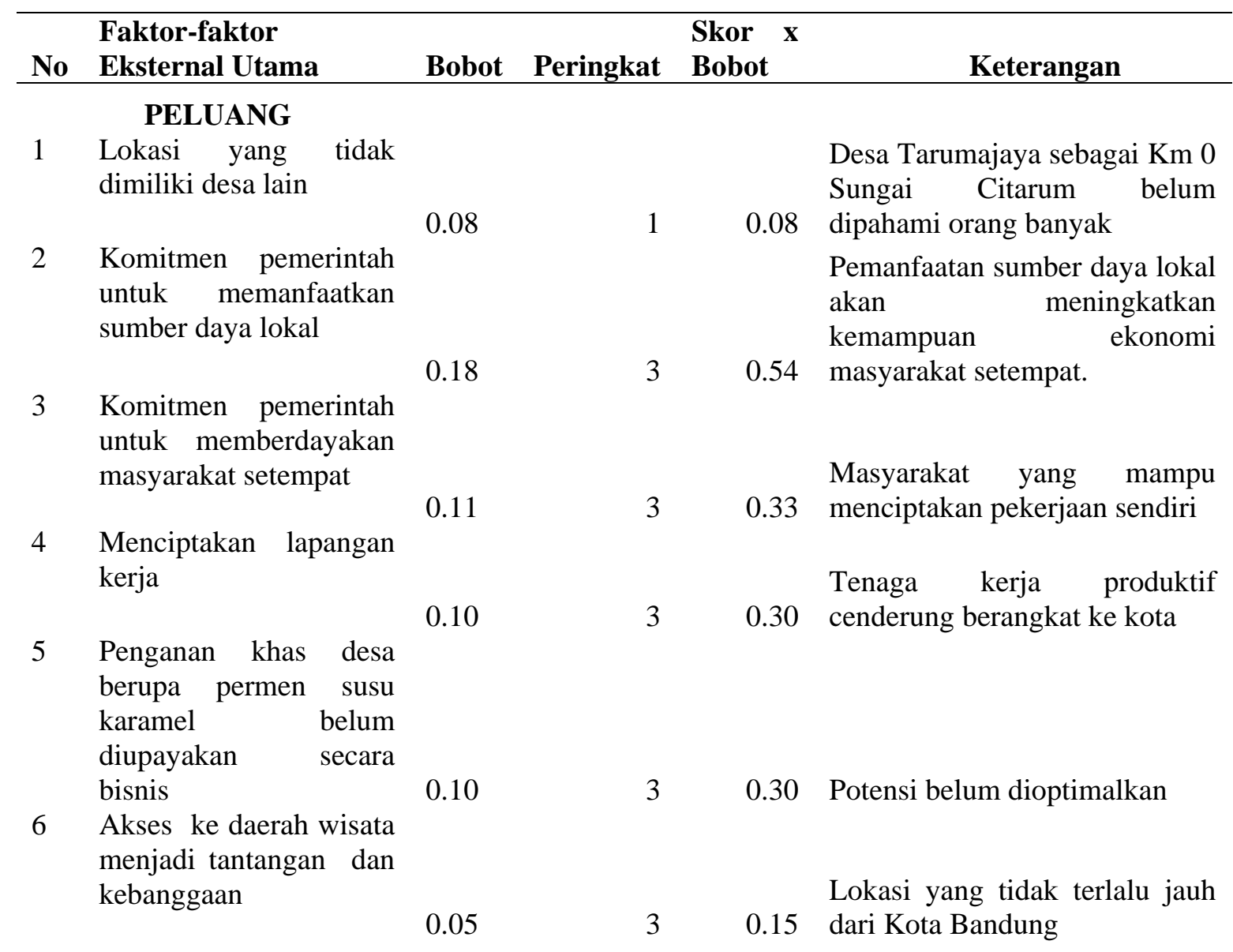

Ekonomi, Sosial, Budaya 
7 Persiapan desa yang beralih fungsi dan budaya

\section{ANCAMAN}

Masyarakat sebelumnya mengalih fungsikan hutan menjadi sawah yang mengakibatkan daerah hulu tidak dapat menyimpan air.

1 Usaha berbahan dasar

bahan baku yang tergantung musim, termasuk usaha berisiko tinggi $0.08 \quad 2 \quad 0.16$ Budidaya belum dilakukan〉

Selera konsumen yang
belum teridentifikasi

0.10 3 0.30

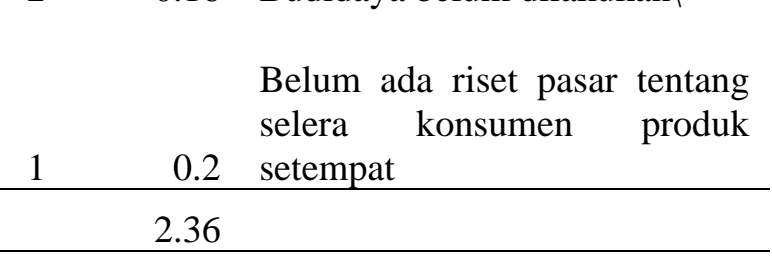

TABEL 2

MATRIKS FAKTOR INTERNAL BUMDES TARUMAJAYA

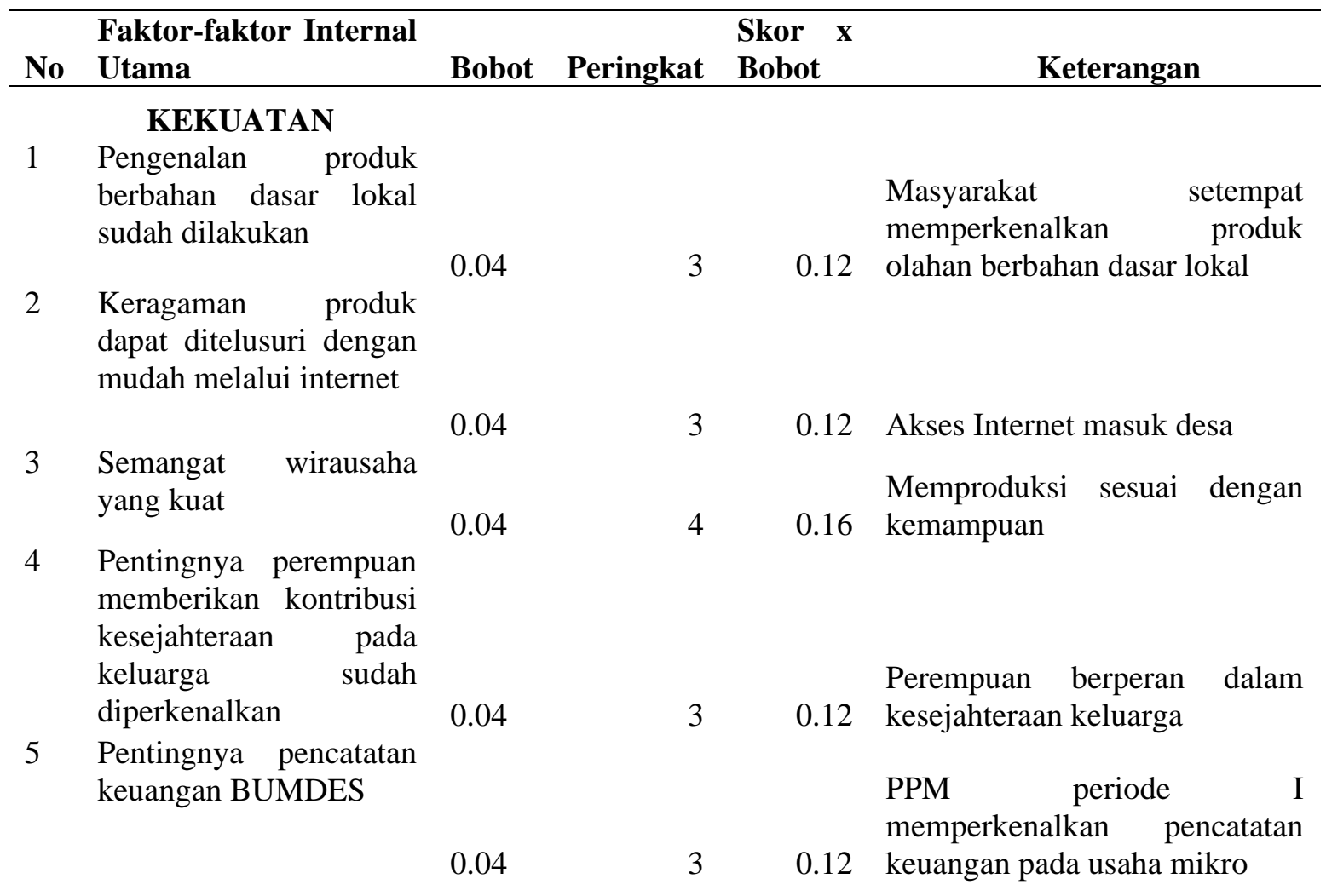


6 Pentingnya kemasan dan pendaftaran produk ke PIRT, BPOM dan MUI

7 Adanya perhatian dari Pemerintah Pusat, khusunya Presiden RI

8 Adaya komitmen untuk 0.06 menjadikan KM 0 Citarum, sebagai daerah wisata dan kembali ke fungsi awal

9 Kebersamaan penduduk setempat

10 Sifat kekeluargaan dan keramahan penduduk setempat

\subsection{2}

PPM periode I memperkenalkan pentingnya pendaftaran produk ke Dinas Perdagangan untuk memperoleh PIRT

PPM periode I memberikan bantuan mesin untuk $3 \quad 0.18$ pengolahan tepung

PPM periode I menghasilkan kerja sama FE UNPAS dengan

11 Produk olahan manual sudah diproduksi, namun belum dijual secara bisnis

12 Gerai penjualan produk IRT dan mikro tersedia namun belum dioptimalkan

\subsection{PemKab Majalengka}

Sikap gotong royong medukung untuk usaha

0.2 bersama

Mendukung untuk melakukan $4 \quad 0.2$ kerjasama bisnis

Ada kemauan untuk 0.24 menghasilkan produk

Gerai hanya buka ketika musim $4 \quad 0.12$ libur, karena tidak ada pembeli

\section{KELEMAHAN}

1 Pengalaman berusaha belum ada

2 Proses produksi manual dan belum optimal

3 Kesulitan bahan baku 0.06 ketika perubahan musim 0.02

4 Standar operasi yang harus dilalui 0.03

5 Modal kerja terbatas

6 Pencatatan yang harus dilakukan 0.06

$\begin{array}{lll}7 & \text { dilakukan } & 0.06 \\ & \text { Pasar belum terbentuk } & 0.06\end{array}$

8 Produk seperti apa yang diperlukan pasar
0.03

\section{$1 \quad 0.07 \quad$ BUMDES baru berdiri}

10.06 Produk tidak memiliki standar

$1 \quad 0.02$ Bahan lokal tergantung musim

$1 \quad 0.03$ Belum ada SOP

$1 \quad 0.03$ Belum mengelola modal kerja

10.06 Pencatatan sederhana

10.06 Belum ada survey pasar

10.04 Belum ada survey pasar
0.04 


\begin{tabular}{clcccl}
9 & $\begin{array}{l}\text { Segmen pasar yang } \\
\text { harus dituju } \\
10\end{array}$ & 0.06 & 1 & 0.06 & Belum ada survey pasar \\
$\begin{array}{l}\text { Program promosi yang } \\
\text { harus dilakukan }\end{array}$ & 0.03 & 1 & 0.03 & Belum ada survey pasar \\
\hline TOTAL & 1.00 & & $\mathbf{2 . 3 1}$ & \\
\hline
\end{tabular}

Berdasarkan matriks faktor eksternal diperoleh nilai total 2,36 dan internal 2,31 dapat dibuatkan gambar berikut untuk menentukan strategi yang tepat bagi BUMDes Tarumajaya dapat dilihat pada Gambar 4.

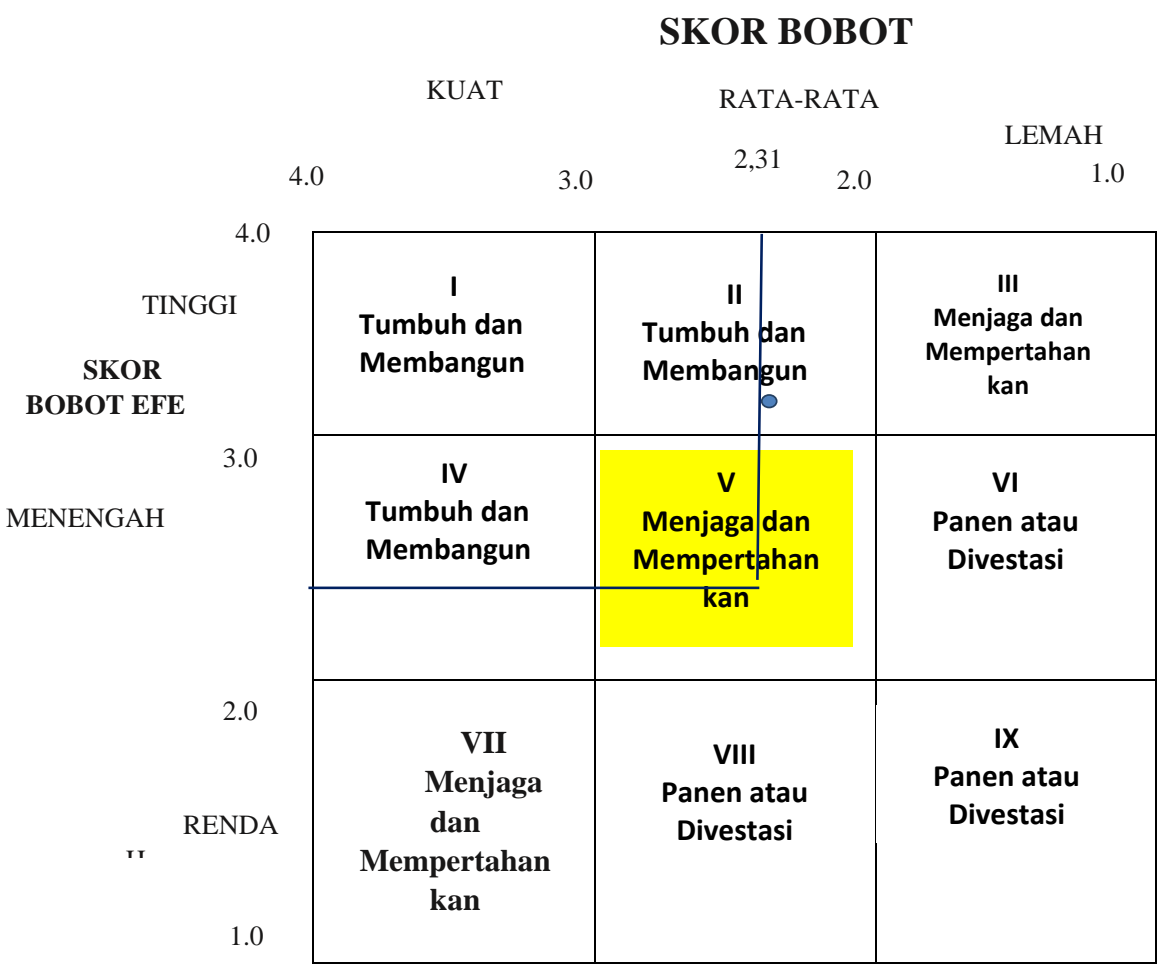

Sumber: David and David alih bahasa Puspasari dan Puspitasari (2016)

\section{Gambar 4 Matriks Internal - Eksternal}

Berdasarkan matriks internal eksternal yang disusun nampak BUMDes Tarumajaya berada pada Kuadran V, dan strategi yang tepat adalah menjaga dan mempertahankan. Dua strategi yang dapat dipilih adalah Penetrasi Pasar dan Pengembangan Produk (David and David alih bahasa Puspasari dan Puspitasari, 2015). Strategi penetrasi pasar adalah mencari pangsa pasar yang lebih besar untuk produk saat ini di pasar yang ada sekarang melalui upaya-upaya pemasaran yang lebih baik. Strategi ini berisiko rendah. Pendekatan yang dapat dilakukan untuk strategi penetrasi pasar meliputi: (1) mempertahankan/meningkatkan pangsa pasar, (2) mendominasi pertumbuhan pasar, (3) menghilangkan pesaing, (4) Meningkatkan penggunaan pelanggan. Wainana dan Oloko (2015) mengemukakan bahwa strategi penetrasi berpengaruh terhadap pertumbuhan perusahaan.

Strategi pengembangan produk adalah mengupayakan peningkatan penjualan melalui perbaikan produk saat ini atau pengembangan 
produk baru. Strategi ini memiliki risiko menengah. Strategi ini memerlukan perubahan operasi bisnis, meliputi: (1) riset dan pengembangan, (2) penilaian kebutuhan pelanggan, (3) kejelasan merk.

Matrix Ansoff sangat bermanfaat untuk perumusan strategi pemasaran. Perancangan meliputi program manajemen fungsional (pemasaran, keuangan, produksi, dan SDM) yang terintegrasi, dimulai permintaan pasar, pembuatan produk, sumber dan penggunaan dana, sampai dengan SDM yang memahami proses bisnis secara profesional.

Product

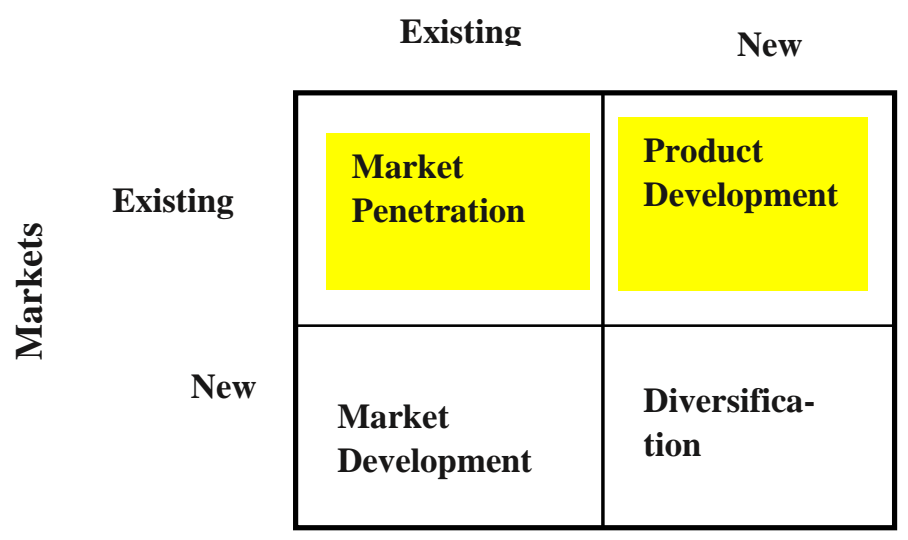

Sumber: Team FME. 2013

\section{Gambar 5 Strategi Pemasaran Alternatif}

Berdasarkan analisis Gambar 5, penetrasi pasar adalah memasarkan produk yang ada untuk pasar yang ada saat ini. Hal ini berarti BUMDesa Tarumajaya dapat lebih agresif untuk menawarkan produk yang ada saat ini di kawasan wisata Situ Cisanti dan di kantor BUMDes, karena lokasinya terletak di arah jalan pulang dari kawasan wisata. Kebiasaan wisatawan nusantara adalah senantiasa mencari oleh-oleh khas setempat sebagai buah tangan keluarga dan sarana promosi lokasi wisata.

Pengembangan produk baru dapat dilakukan dengan bekerja sama dengan warga setempat terutama ibu PKK untuk senantiasa mengembangkan produk baru dengan memanfaatkan teknologi informasi untuk benchmarking produk yang dikembangkan di desa lain. Ide-ide yang mucul melalui program pengabdian yang telah dilakukan adalah membuat kripik kentang, wortel, manisan cabe, kaos bergambar situ Cisanti, gunung Wayang, dan sebagainya.

Ide-ide yang muncul harus dikembangkan dalam bentuk model kanvas bisnis, yang meliputi segmen pelanggan, proposisi nilai perusahaan, hubungan pelanggan, saluran distribusi produk, kegiatan utama, sumber daya kunci, aliran pendapatan dan struktur biaya. Pelatihan cara pengisian sudah diberikan, namun semangat wirausaha masih perlu diuji apalagi menjalankan bisnis dalam tahap pengenalan.

Keterlibatan masyarakat dalam kegiatan produksi dimaksudkan untuk menambah pendapatan keluarga dan produk tidak dijual secara individual di lokasi wisata, karena TNI AD atas intruksi PANGDAM III Siliwangi senantiasa menjaga kawasan tersebut dan tidak mengijinkan adanya kaki lima berjualan di lokasi wisata. BUMDes dapat berperan sebagai gerai/outlet atas produk penduduk setempat, namun kualitas, kemasan, pencantuman merk, komponen, masa kadaluarsa (untuk produk makanan) senantiasa diingatkan, untuk menjaga image konsumen atas produk penduduk setempat. Adanya partisipasi masyarakat dapat memberikan kontribusi pada kemajuan BUMDes (Tama dan Yanuardi, 2015).

Kepemimpinan dan kualitas SDM pengelola BUMDes memiliki peran penting dalam menjalankan bisnis di desa. Idealnya memiliki kompetensi dan kapasitas dalam menjalankan aktivitas BUMDes, memiliki jiwa wirausaha yang memadai sehingga bisnis dapat berjalan dengan baik dan mampu meningkatkan perekonomian 
masyarakat desa (Syaputra, et. al., 2017). Pengelolaan BUMDes yang tidak baik dapat mengakibatkan semua bidang usaha tidak berjalan dan tidak dapat menyokong pendapatan desa, sehingga eksistensinya sebatas papan nama (Ramadana, et. al., 2013).

BUMDes dan Pemerintah Desa memiliki relasi yang erat, karena Pemerintah Desa menjadi pengawas dari kegiatan yang dilakukan BUMDes (Anggraeni, 2016). Pemerintah Desa sebagai pemilik modal berhak melakukan pengawasan namun tidak serta merta ikut menentukan operasi dan kebijakan perusahaan, sehingga terjadi pendelegasian wewenang kepada pengurus BUMDes secara profesional mengelola bisnis yang menguntungkan. Hal yang menjadi tantangan bagi BUMDes dan Pemerintah Desa adalah menjaga keseimbangan relasi, diman dominasi satu pihak terhadap pihak lainnya perlu dihindari.

\section{KESIMPULAN}

Kesimpulan yang diperoleh dari Pengabdian Kepada Masyarakat di Kawasan hulu sungai Citarum desa Tarumajaya Kabupaten Bandung adalah: (1) BUMDes Tarumajaya dapat diandalkan sebagai outlet/gerai yang menampung hasil produksi penduduk setempat dan menghasilkan keuntungan asalkan dikelola secara profesional dengan memperhatikan model kanvas bisnis yang lebih lengkap. (2) Perumusan strategi yang tepat adalah penetrasi pasar dan pengembangan produk. Artinya pengurus BUMDes harus senantiasa melakukan promosi ekowisata melalui media sosial untuk mengundang jumlah kunjungan ke situ Cisanti serta memotivasi penduduk untuk berinovasi menghasilkan produk yang beragam sesuai dengan selera konsumen serta senantiasa memperhatikan kualitas produk yang dihasilkan juga upaya yang dilakukan pesaing.

\section{UCAPAN TERIMAKASIH}

Penulis mengucapkan terimakasih yang sebesar-besarnya kepada DRPM Kemenristekdikti yang telah memberikan kontribusi dana hibah dalam kegiatan Pengabdian Masyarakat (PKM) tahun anggaran 2019, juga kepada Lembaga Pengabdian Masyarakat (LPM) dan Fakultas Ekonomi dan Bisnis Universitas Pasundan yang telah memberikan dukungan kegiatan PKM ini. Demikian pula disampaikan terima kasih kepada Kepala Desa beserta jajarannya dan Pengurus BUMDes Tarumajaya atas kerjasamanya yang sangat baik.

\section{REFERENSI}

Anggraeni, Maria Rosa Ratna Sri. 2016. Peranan Badan Usaha Milik Desa (BUMDES) pada Kesejahteraan Masyarakat Pedesaan. Studi pada BUMDES di Gunung Kidul, Yogyakarta. Modus Vol. 28 (2): 155 -167.

David, Fred R. and Forest R. David. 2016. Manajemen Strategik. Alih bahasa oleh Novita Puspasari dan Liza Nurbani Puspitasari. Salemba Empat. Jakarta.

Dewi, Amelia Sri Kusuma. 2014. Peranan Bada Usaha Milik Desa sebagai Uapaya dala Meningkatkan Pendapatan Asli Desa serta menumbuhkan Perekonomian Desa. Journal of Rural and Development. Vol. V No. 1 Februari.

Goma, Subhan. 2015. Peran Pemerinah Desa dalam Meningkatkan Pendapatan di Desa Bolangitang Satu Kecamatan Bolang Itang Kabupaten Bolaang Mongondow Utara. https//ejournal.unsrat.ac.id

Kecamatan Kertasari Dalam Angka. 2018. Badan Pusa Statistik Kabupaten Bandung.

Ramadana, Coristya Berlian; Heru Ribawano; Suwondo. 2013. Keberadaan Badan Usaha Milik Desa (BUMDES) sebagai Penguatan Ekonomi Desa (Studi di Desa Landungsari, Kecamatan Dau, Kabupaten Malang). administrasipublik.studentjournal.ub.ac.id

Sembiring, Sentosa. 2017. Keberadaan Badan Usaha Milik Desa dalam Meningkatkan Pendapatan Asli Desa. Kertha Patrika. Volume 39. Nomor 1. April.

Sulaksana, Jaka dan Irni Nuryanti.2019. Strategi Pengembangan Badan Usaha Milik Desa (BUMDes) Kasus di BUMDes Mitra Sejahtera Desa Cibunut Kecamatan Argapura Kabupaten Majalengka. Jurnal Ekonomi Pertanian dan Agribisnis (JEPA) Vol. 3 No. 2: 348 - 359.

Syaputra, Rialdi; Asnelly Ridha Daulay; Elwamendri. 2017. Model Pengembangan BUMDes Guna Meningkatkan Inovasi dan

$$
\text { Ekonomi, Sosial, Budaya }
$$

1096 
kemandirian Masyarakat di Provinsi Jambi. Pemerintah Provinsi Jambi. Badan Penelitian dan Pengembangan Daerah. asnelly69.files.wordpress.com/2018/06/lapo ran-penelitian-bumdes

Tama, Dantika Ovi Era dan Yanuardi. 2015. Dampak Badan Usaha Mllik Desa bagi Kesejahteraan Masyarakat di Desa Karangrejek Kecamatan Wonosari Kabupaten Gunung Kidul.
Team FME. 2013.www.free-management- ebooks.com
Wainaina, Gideon Njomo and Margaret Oloko. 2015. Market Penetration Strategies and Organizational Growth: A Case of Soft Drink Sector in Kenya. International Journal of Management and Commerce Innovations.Vol. 3 Issue 2, pp 219-227, October.

https://eprints.uny.ac.id 